International Research Journal of Management, IT \& Social Sciences
Available online at https://sloap.org/journals/index.php/irjmis/
Vol. 6 No. 5, September 2019, pages: 65 72
ISSN: 2395-7492
https://doi.org/10.21744/irjmis.v6n5.705

\title{
Technical Assessment of Energy Quality on Guillen Stream, Abdón Calderón Parish
}

\author{
Alcira Magdalena Vélez Quiroz ${ }^{\text {a }}$ \\ Miriam Lourdes Filgueiras Sainz de Rozas ${ }^{b}$ \\ Miriam Vilaragout Llanes ${ }^{c}$ \\ Gino Mieles Miles ${ }^{\mathrm{d}}$ \\ Antonio Vázquez Pérez ${ }^{\mathrm{e}}$
}

\section{Article history:}

Received: 09 March 2019

Accepted: 31 May 2019

Published: 21 August 2019

\section{Keywords:}

energy quality;

isolated systems;

microgrids;

photovoltaic;

systems;

\begin{abstract}
The rural areas of Abdón Calderón Parish are sites that today their population does not receive an adequate consumption of energy, first because the communities are far from the generation center and second because of the difficult access conditions of the territory studied. The power lines have installed next to the ravines where most of the population crosses rivers and streams, which cause difficulties mainly of humidity, falling poles among others, causing poor quality of service to consumers. Renewable sources of energy have distributed in the territory; one of the most prominent sources is solar energy, where solar radiation levels are high. The solution to the problems of the quality of energy in a first stage can have solved with small microgrids implementing photovoltaic systems, for this, we have been working on knowing the levels of penetration that can have assumed by the electrical system. The objective of the research is to be able to demonstrate the elements that conspire with the poor quality of the energy and propose in first stage microgrids that take advantage of solar radiation with the implementation of photovoltaic systems. Where their power depends on the needs of the network because a service with higher quality and reliability can has provided, reducing maintenance and installation costs. The methodology applied was the site visit, interviews, routes that allowed referencing the amount of poles and existing transformers.
\end{abstract}

2395-7492@ Copyright 2019. The Author. This is an open-access article under the CC BY-SA license (https://creativecommons.org/licenses/by-sa/4.0/) All rights reserved.

\section{Author correspondence:}

Alcira Magdalena Vélez Quiroz,

Universidad Tecnica de Manabi, Carrera en Ingeniería en Electricidad, FCMFQ. Urbina and Che Guevara Avenue, Portoviejo, Ecuador. Email address: maqvelez@utm.edu.ec

a Universidad Tecnica de Manabi, Portoviejo, Ecuador, maqvelez@utm.edu.ec

b Universidad Tecnologica de la Habana, Avenida, Cuba, miriaml@electrica.ispjae.edu.cu

c Universidad Tecnologica de la Habana, Avenida, Cuba, miriamv@electrica.cujae.edu.cu

d Empresa Electrica (CNEL), Portoviejo, Ecuador, mielesvelezginojoaquin@gmail.com

e Universidad Tecnica de Manabi, Portoviejo, Ecuador, antoniov5506@gmail.com 


\section{Introduction}

At present, the role of the energy system is one of the priorities of the scientific, political, economic and social agenda; given the wide repercussions, it has on the whole of social life. The depletion of fossil fuel resources and climate change because of greenhouse gas emissions have expected to generate a series of challenges that transcend individual actors and national environments and require the search for common solutions.

Petroleum and nuclear fuels appeared and took root in the daily life of man as the elements that would propitiate the eternal solution of human problems in terms of their energy needs. However, they cannot even ensure sustainability, understood as the capacity of a system to develop with its own resources, so that its operation does not depend on external sources, even if they have considered (Montesinos, 2010; Cedeno et al., 2017; Chilán et al., 2018).

It has demonstrated that the responsibility of the man in front of the process of loss of the biological diversity and the exhaustion of the natural resources has given in a rhythm that oscillates between a thousand and ten thousand times faster than the process that occurs of natural form. On this basis, the loss during the XXI century of two-thirds of all existing species and the depletion of hydrocarbons and other mineral resources. Necessary for development is calculated, which in terms of living species is equivalent to the disappearance produced in the It was a Cretaceous period that took five million years for the ecological balance to has been achieved, that is, five times the age of man on earth (Viamonte, 2007; Gamez et al., 2016; 2017).

People, who reside in rural areas where electricity has not arrived, lead a difficult life with serious limitations to perform social tasks at night; do not have access to the media and for half of the 24 hours a day silence and darkness prevail for their social life (Rodríguez et al., 2016).

Access to electricity generates the potential for improving the quality of life and the active incorporation of people into a healthy and integrated social life. Access to electricity services reduces marginality, increases citizen security, and improves public health and education among other advantages.

In the current guidelines reflected in the National Development Plan 2017-2021, "A whole life". The change of the matrix has called to become a political tool, for planning work aimed at changing the composition of electricity generation with the incorporation of sources of renewable resources and be able to guarantee energy autonomy, with the goal of consolidating an energy base of undoubted sustainability (CNP, 2017).

Rural electrification constitutes an important challenge for the Ecuadorian government, in order to achieve the objectives outlined in the National Development Plan 2017-2021 (CNP, 2017), for rural people. The supply of energy contributes to reducing poverty rates, marginality and improve sanitary conditions, promoting economic growth through competitiveness and the increase of agricultural production.

The objective of the work is to demonstrate through a study conducted in rural areas of the province of Manabí, the feasibility of using photovoltaic technology to ensure rural electrification, in order to achieve greater efficiency and quality of electric service in areas isolated

Abdón Calderón is a rural parish of the Portoviejo canton, dedicated mainly to agriculture and in small proportions to livestock, in which there are approximately 19 rural communities dedicated to agriculture, 8 urban and other small isolated communities. Most of them are located on the banks of the Chico River and streams of the same name, other tributaries such as Mancha Grande and Chirijos supply the river, this is the area of greatest relief of the territory. In winter, its rainfall is high with temperatures up to 35 degrees with the high level of the forest to be a purely mountainous territory.

All communities are electrified from feeder 1 San Placido, sub-station Playa Prieta (Rodríguez et al., 2018; Ramos et al., 2018). Despite the distance of the network between 5 and $20 \mathrm{~km}$ with single-phase branches of the main feeder until the last subscriber of each community, with a medium voltage line that feeds distribution transformers of small capacities (5,10 and $15 \mathrm{kVA}$ ). Depending on the consumers of each site, arranged in low voltage network, for the supply of 120 or 220 Volts in some sites.

The medium and low voltage networks are bordering the ravines that are usually the access routes of these communities, where they have exposed to the inclemency of weather and nature (climatology, fauna, and flora) agents that in one way or another do not guarantees that the quality and electric service is stable.

The objective of this research is to search for solutions that improve the quality of energy using renewable sources, based on the knowledge of the study area and the potentials that have studied in the Guillen creek. 


\section{Materials and Methods}

A literature review related to the behavior of energy quality in different territories was carried out and how this problem, behaved in Ecuador, mainly the province of Manabí. Other results obtained in the municipality of Chone were evaluated (Rodriguez, 2016; Pérez et al., 2016; 2017) and the QGIS (2018), was used as software to reference the communities of the Abdón Calderón parish, the power lines, rivers, roads and ravines, elements that today influence the poor quality of the energy of rural zones. To know the solar potential and the productivity of the photovoltaic systems, we worked with the solarGIS (SOLARGIS, Geographic information - Metadata, 2017).

\section{Results and Discussions}

The Guillen gulch is located at the foot of the mountain and its communities have deployed from the ravines to the lower parts, conspiring this with the provision of electricity networks, as they have to cross the mountainous area. To reach the consumer in figure 1, we can see the location of the parish within the province of Manabí (A) and the gulch of Guillen within the parish (B).

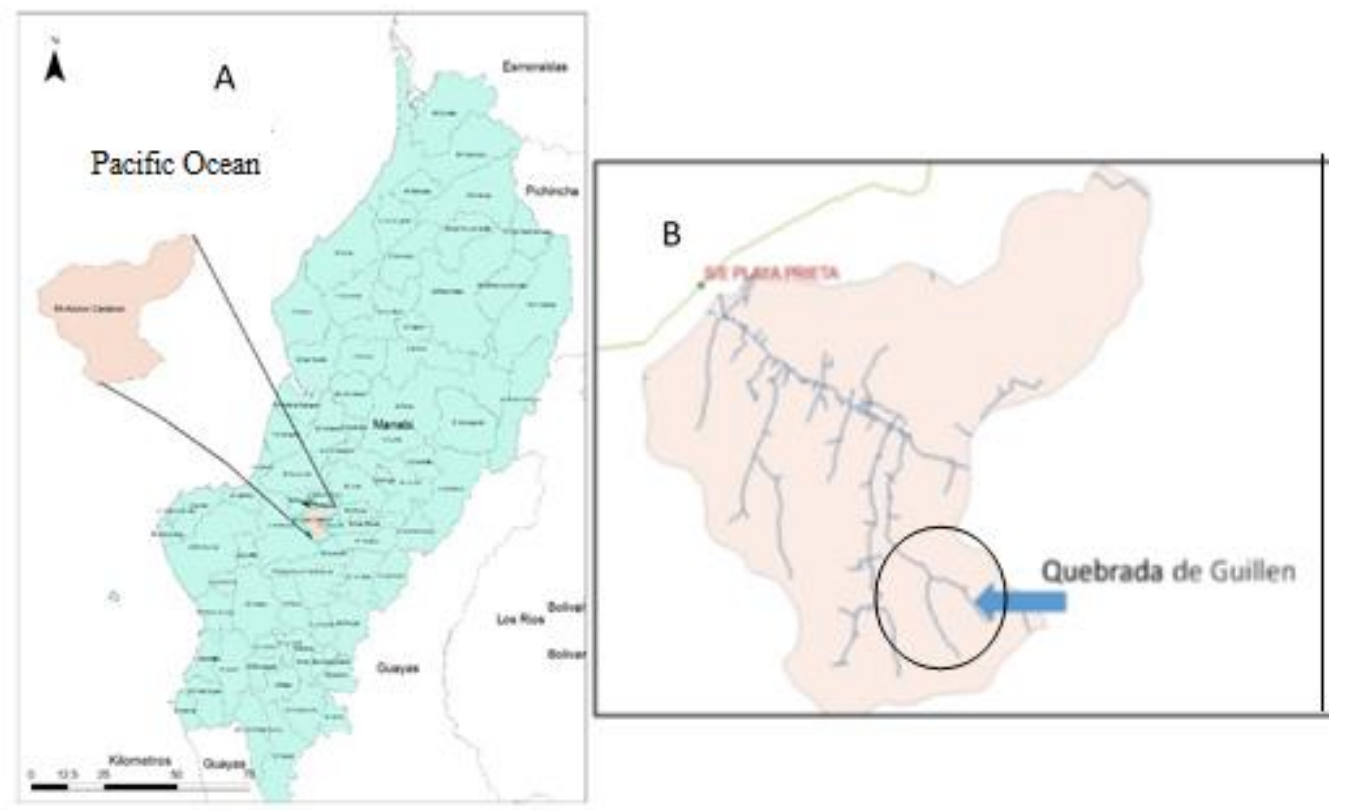

Figure 1. Location of Abdón Calderón Parish (A) and (B) Guillen Stream

The quality of energy results from continuous attention; In recent years, this attention has been of greater importance due to the increase in the number of sensitive loads in the distribution systems, which, by themselves, constitute a cause of the degradation in the quality of electric power.

Figure 2 shows some images of the configuration of the territory and how the accessories of the electrical network (A) have transferred and the location of the lines as shown in (B) in rigorous conditions of the terrain in many cases humidity due to being close to the rivers.

Quiroz, A. M. V., Rozas, M. L. F. S. de, Llanes, M. V., Miles, G. M., \& Pérez, A. V. (2019). Technical assessment of energy quality on guillen stream, abdón calderón parish. International Research Journal of Management, IT and 

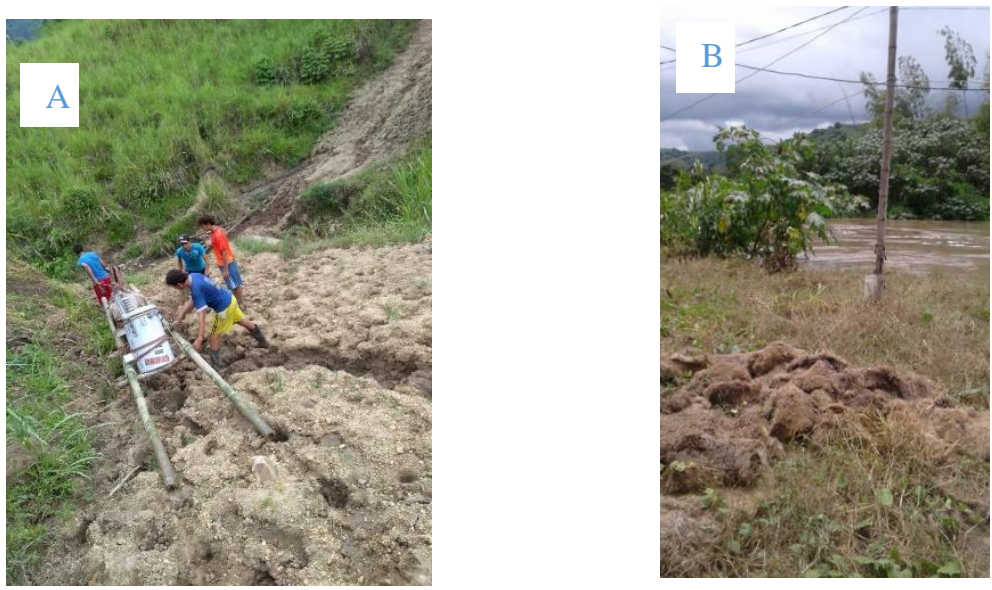

Figure 2. Images of the adverse conditions of the Guillen creek

The quality of energy can have defined when electrical energy has supplied to equipment and devices with the appropriate characteristics and conditions that allow them to maintain their continuity without affecting their performance, or cause failures to its components (UPME, 2011). As can be seen in figure 2, the conditions where electrical networks are located is not adequate, so in the transfer stage it is difficult and when the breakdowns occur it is very difficult to arrive, more rigorous when it is the winter period (January-May).

From the technical point of view for an electrical installation to be efficient, four basic elements must be ensured (Jordi, 2009), management and optimization of the contracting; internal energy management through measurement and supervision systems; demand management and; improvements in productivity through the control and elimination of disturbances.

Currently, some applications linked to renewable energy sources have considered suitable to improve the technical parameters of the network in areas with a high load, there are different ways to bring electricity to the homes of isolated rural communities, one of them is the extension of the network, the micro-networks or isolated networks and the domiciliary systems (Parrondo, 2012).

Electrifying the rural environment entails supplying electricity to all communities, regardless of the technology, the energy sources used and the form of generation used. Rural electrification has mainly characterized by a low local charge density, which is why feasibility studies must have carried out that economically satisfy the technological variant used (Rodríguez et al., 2016).

In the rural area, electrification has carried out preferentially through the extension of the electricity network, with very low utilization of renewable sources and distributed systems of generation and supply of energy, so that the electric service in these areas generates many losses, what affects the quality of it, especially in the stability of the network voltage. The problems increase in the winter when the rains arrive, where the interruptions become more frequent and the solution to the problems is more complex.

In order to know the vulnerable points in the Guillen parish, a bonding project was developed where the points of the poles and the transformers were taken; in figure 3 the fieldwork carried out is shown. 


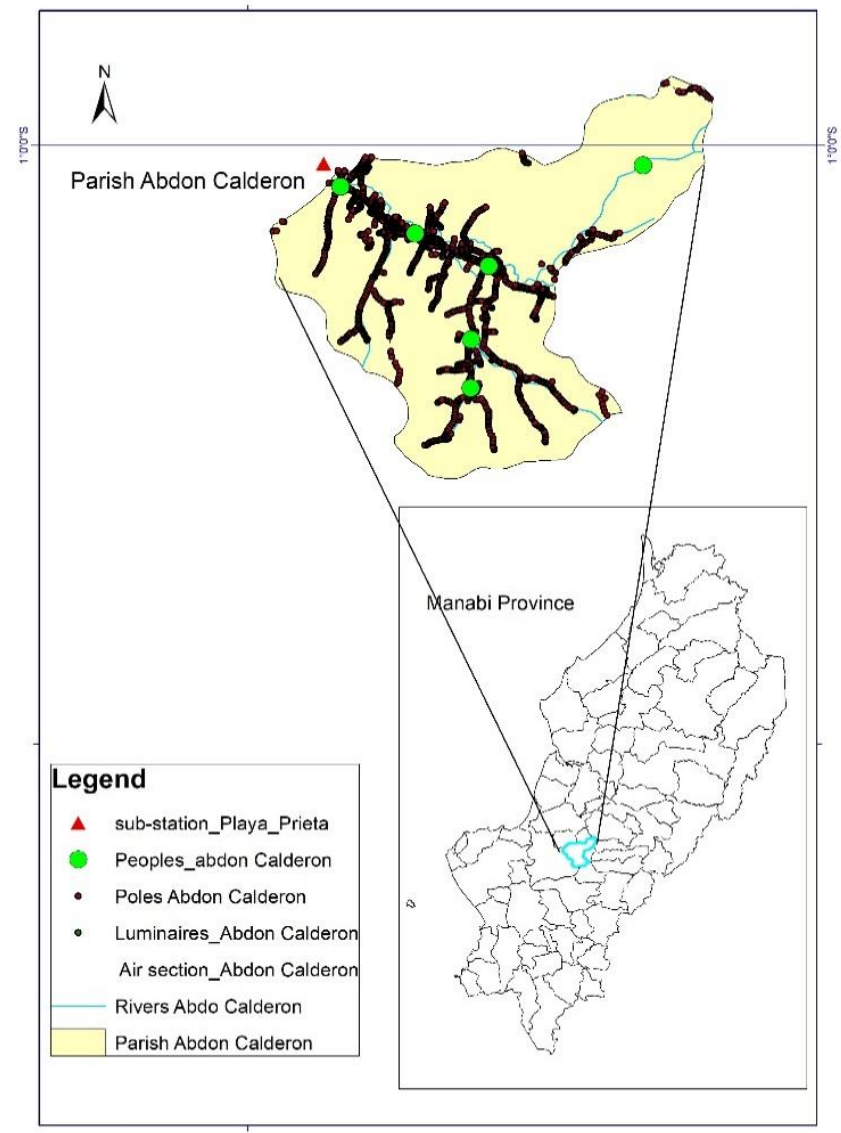

Figure 3. Poles and transformers of the ravine of the study area

In the parish, some relevant studies have carried out with the possibility of installing photovoltaic systems (Carreño $e t$ al., 2018). These can be of two types: a) unconnected systems to the network, which can have systems of accumulation of energy (batteries) or can have a simpler configuration, without batteries (autonomous) and b) systems connected to the network (Saltos et al., 2017). A photovoltaic array (set of solar modules) and an inverter integrate the interconnected photovoltaic (SF) systems, which is an electronic device that converts from direct current to alternating current. These do not have energy accumulation devices since the energy produced during the hours of insolation has channeled to the electric network.

Autonomous Photovoltaic Systems (SFA) is probably one of the most modern renewable energy systems for autonomous rural electrification worldwide, given that more than 500,000 rural households have these electrification systems, throughout the world. Among the most relevant advantages of OSS, it is found that, for their operation, they only depend on solar radiation as an energy resource, they do not require the supply of fuel (necessary in the generators or hybrids), which represents a problem for the electrification in rural communities (Rodríguez et al., 2011).

This analysis was carried out based on the radiation data offered by the SOLARGIS. where the long-term average annual solar radiation data of the daily total irradiation totals in optimal inclination (GTI), in $\mathrm{kWh} / \mathrm{m}^{2}$, covering the period 1999-2015 (SOLARGIS, 2017), where ISO standards 19115: 2003, Geographic information - Metadata (ISO, 2014), is met, which is a working tool that is used to know the radiation values on the cartography of the study area.

Figure 4 (A), shows the whole of Ecuador and where the behavior parameters are observed in the province of Manabí and in (B), long-term annual average of the potential production of photovoltaic electricity is observed (PVOUT), is the evaluation of the potential of photovoltaic energy production for an independent plant with modules mounted with an optimum inclination to maximize the annual photovoltaic production of Ecuador (SOLARGIS, Geographic information - Metadata, 2017).

Quiroz, A. M. V., Rozas, M. L. F. S. de, Llanes, M. V., Miles, G. M., \& Pérez, A. V. (2019). Technical assessment of energy quality on guillen stream, abdón calderón parish. International Research Journal of Management, IT and Social Sciences, 6(5), 65-72. https://doi.org/10.21744/irjmis.v6n5.705 
The information is referenced in such a way that at any point on the map of the previous figures the values that are represented in each site are shown, allowing knowing the generation behavior for each area of the country, mainly the rural one. What helps to know what products you have and allows you to draw strategies to solve the problems of poor quality of energy in the areas studied.
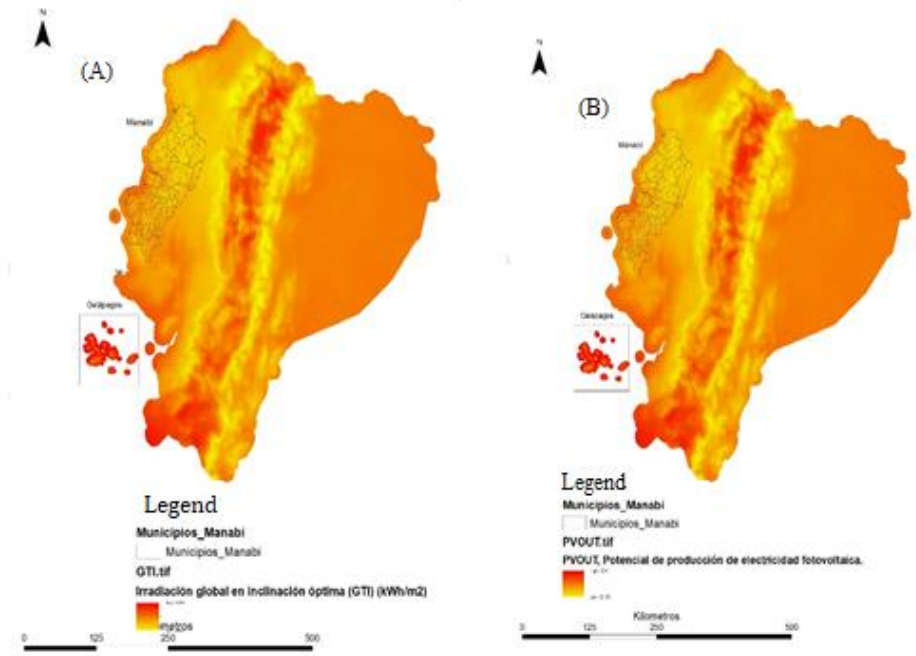

Figure 4. Solar irradiation of Ecuador (A) and Potential of photovoltaic energy generation (B)

In the fieldwork, the quantity and capacity of the transformers and the houses that have linked as shown in table 1, have obtained. It is noted that the largest number of installed transformers have a capacity of $15 \mathrm{kVA}$, which feed approximately 10 homes each.

Table 1

Number of transformers and dwellings that feed

\begin{tabular}{lll}
\hline $\begin{array}{l}\text { Number of } \\
\text { transformers }\end{array}$ & Capacity (kVA) & $\begin{array}{l}\text { No. of } \\
\text { dwellings }\end{array}$ \\
\hline 3 & 5 & 13 \\
4 & 10 & 14 \\
20 & 15 & 127 \\
1 & 25 & 10 \\
Total & 55 & 164 \\
\hline
\end{tabular}

Analyzing the totals it has observed that there are installed 28 transformers with a capacity of $55 \mathrm{kVA}$, which feed 164 houses in the study area. The fundamental problem in this area due to the studied conditions is that when there is a breakdown of a transformer the conditions are around no less than 10 homes.

Taking into account that these breakdowns cannot be repaired quickly because it is necessary to look for the appropriate climatological conditions, the affected populations can be between 3 and 6 months with interruption of the service, hence looking for other alternatives with renewable resources, in this case, solar energy. It is a viable and feasible solution in the Guillen creek and other areas with the same difficulties of poor quality of the electric service.

\section{Conclusion}

a) It is technically, economically, environmentally and socially viable to introduce the photovoltaic technology connected to the low voltage network of the houses studied in the Abdón Calderón parish, with the aim of improving the energy quality of rural areas. 
b) The intensity quality and availability of solar potential throughout the year in the Abdón Calderón parish, allows the introduction of photovoltaic technology to generate electric power, with a competitive performance with any other technologies and existing generation sources,

c) Which will allow improve the quality of the electric service, reduce losses, reduce the cost of kWh generated and served, preserve natural resources and contribute to avoiding COemissions 2 into the atmosphere?

Conflict of interest statement and funding sources

The authors declared that they have no competing interest.

Statement of authorship

The authors have a responsibility for the conception and design of the study. The authors have approved the final article.

Acknowledgments

Special thanks to the students who have worked to carry out this research in areas of very difficult access.

Quiroz, A. M. V., Rozas, M. L. F. S. de, Llanes, M. V., Miles, G. M., \& Pérez, A. V. (2019). Technical assessment of energy quality on guillen stream, abdón calderón parish. International Research Journal of Management, IT and Social Sciences, 6(5), 65-72. https://doi.org/10.21744/irjmis.v6n5.705 


\section{References}

Arauz, WMS, Gámez, MR, Pérez, AV, Castillo, GAL, \& Alava, LAC (2017). The future of micro-grids in Ecuador. International Journal of Physical Sciences and Engineering , 1 (3), 18. https://doi.org/10.21744/ijpse.v1i3.53

Cedeno, M. L. D., Arteaga, M. G. D., Perez, A. V., \& Arteaga, M. L. D. (2017). Regulatory framework for renewable energy sources in Ecuador case study province of Manabi. International Journal of Social Sciences and Humanities, 1(2), 29-42. https://doi.org/10.29332/ijssh.v1n2.33

Chilán, J. C. H., Torres, S. G. P., Machuca, B. I. F., Cordova, A. J. T., Pérez, C. A. M., \& Gamez, M. R. (2018). Social impact of renewable energy sources in the province of Loja. International Journal of Physical Sciences and Engineering, 2(1), 13-25. https://doi.org/10.29332/ijpse.v2n1.79

CNP. (2017). National Development Plan 2017-2021. A lifetime "National Council for Planning and National Development Planning Secretariat. Senplades.

Gamez, M. R., Perez, A. V., Arauz, W. M. S., \& Jurado, W. C. C. (2016). Sustainable transformation of energy matrix. International Research Journal of Engineering, IT \& Scientific Research, 2(9), 37-43.

Gamez, MR, Perez, AV, Sera, AS, \& Ronquillo, ZM (2017). Renewable energy sources and local development. International Journal of Social Sciences and Humanities , 1 (2), 1019. https://doi.org/10.29332/ijssh.v1n2.31

ISO. (2014). ISO 19115: 2003. Geographic information - Metadata. https://www.iso.org/standard/26020.html

Jordi, S. (2009) Technical Guide Electrical Energy Efficiency Circutor SA ISBN-13: 978-84-612-0421-2 http://circutor.com/docs/Guide_EEE_EN-LR.pdf

Montesinos, P., González, J. D., González, J., Rayón, C., De Lisa, E., Amigo, M. L., ... \& Debén, G. (2010). Therapyrelated myeloid neoplasms in patients with acute promyelocytic leukemia treated with all-trans-retinoic acid and anthracycline-based chemotherapy. Journal of Clinical Oncology, 28(24), 3872-3879.

Parrondo, J. L. (2012). Integrated planning of electrification using GIS. . Quito. Ecuador: Annals of mechanics and electricity January-February 2013.

Pérez, A. V., Castillo, G. A. L., Alava, L. A. C., \& Chilan, J. C. H. (2016). The regulatory framework for renewable energy sources. International Research Journal of Management, IT and Social Sciences, 3(11), 8-21.

Perez, A. V., Gamez, M. R., Viteri, C. G. V., \& Quiroz, A. M. V. (2017). Community power as a driving force for sustainable local development. International Research Journal of Engineering, IT \& Scientific Research, 3(4), 819.

QGIS. (2018). The current version is QGIS 3.6.1 https://es.wikipedia.org/wiki/QGIS

Ramos, JLM, Pérez, AV, Gámez, MR, \& Zambrano, RVH (2018). Renewable energy sources on the change of energy matrix in Manabí province. International Research Journal of Engineering, IT \& Scientific Research , 4 (4), 17 29. https://doi.org/10.21744/irjeis.v4n4.255

Rodriguez G. M, Vázquez P. A. Velez Q. M. A. (2018). Improved power quality photovoltaic systems in areas. Scientific Journal, 3(3), 265-274.

Rodríguez G. M., Castillo J. W., Saltos W. C, Vazquez P. A. (2016).The extension of the electrical network (rural communities of Chone, 1(1).

Rodríguez, B.(April 2011). Dimensioning by simulation of photovoltaic solar energy systems applied to rural electrification. Scielo, 14(1). http://scielo.sld.cu/scielo.php?script=sci_arttext\&pid=S0864-34662013000500008

Solargis (2017), Geographic information - Metadata, Energy Sector Management Assistance Program (ESMAP), www.solargis.com

Suarez, K. L. C., Carlos, A. G. J., Cuenca, L. A. S., Zambranod, J. A. G., \& Ponce, Ángel A. A. (2018). Demand in abdon calderon parish for possible installation of photovoltaic systems. International Journal of Physical Sciences and Engineering, 2(3), 62-69. https://doi.org/10.29332/ijpse.v2n3.218

UPME (2011). (Quality of electricity "Project Mining energy Planning Unit of Colombia and Colombian Institute for the Development of Science and Francisco José de Caldas Technology, COLCIENCIAS.

Viamonte, GE (2007) Environmental law Cuban. Havana. Felix Varela. Book, ISBN: 978-959-07- 0434-5, Second edition updated and enlarged. 